\title{
Spatial and Temporal Evolution of Low Water Flows in the Sassandra River Catchment Area in Cote d'Ivoire
}

\author{
Djoro Gauthier-Lopez Anouman, Yao Alexis N'go, Gneneyougo Emile Soro, Tié Albert Goula Bi \\ Environmental and Geosciences Laboratory, Nangui Abrogoua University, Abidjan, Côte d'Ivoire \\ Email: anoumandjorolg@gmail.com
}

How to cite this paper: Anouman, D. G.-L., N'go, Y. A., Soro, G. E., \& Bi, T. A. G. (2019). Spatial and Temporal Evolution of Low Water Flows in the Sassandra River Catchment Area in Cote d'Ivoire. Journal of Geoscience and Environment Protection, 7, 184-202.

https://doi.org/10.4236/gep.2019.76015

Received: May 7, 2019

Accepted: June 27, 2019

Published: June 30, 2019

Copyright $\odot 2019$ by author(s) and Scientific Research Publishing Inc. This work is licensed under the Creative Commons Attribution International License (CC BY 4.0).

http://creativecommons.org/licenses/by/4.0/

CC) $\underset{\mathrm{EY}}{ }$ Open Access

\begin{abstract}
In a context of climate change and declining water resources, knowledge of low flow is essential. Present study deals with the spatial and temporal evolution of the streams low flow in Sassandra river. In the study, 12 stations of the Sassandra sub-basins (Sassandra, N'zo, Lobo, and Davo) were selected according to the availability and quality of long-term data. Annual, monthly and daily low flow data from twelve hydrological stations of the Sassandra watershed were used and cover the period from 1970 to 2015. The methodology used is concerned with extracting the low flow data and analyzing and evaluating the trends (Mann-Kendall) and change-point (cumulate sum) of low flow data. Statistical tests are applied to the mean and variance of the low-flow series. The results of the statistical tests show more trends and change points on the mean than on the variance. Significant trends show an increase in low flow waters. The significant change point detected by the cumulative sums test generally occurs between 1990-2007. In addition, tributaries are more affected by significant trends and change point detection than Sassandra river.
\end{abstract}

\section{Keywords}

Low Flow, Mann-Kendall, Cumulate Sum, Sassandra River, Cote d'Ivoire

\section{Introduction}

Water resources are currently under the influence of many natural or anthropogenic phenomena. Of those, the low flow is probably one of the most important phenomena affecting the water resource. In fact, low water is defined as a natural phenomenon corresponding to a decrease in river flow, or even drying up over a 
certain period. In fact, low water is defined as a natural phenomenon corresponding to a decrease in river flow, or even drying up over a period (Garcia, 2016). With population growth and socio-economic development, the demand for water continues to increase. This often results in an increase in pumping, irrigation, etc., which increases the water deficit, especially during these low water periods. The impact of low water levels on the volume of water available can lead to many problems. In Côte d'Ivoire, the Loka River that supplies the city of Bouake in the center of the country dried up in 2018. This situation has led the Ivorian authorities to drilling water. Water drilling has not given important flows in this locality. The phenomenon of low water levels is therefore a concern through the problem of better water resource management and a better understanding of the processes that influence this phenomenon and their evolution. The progressive exploitation of water resources, therefore requires a thorough knowledge of the characteristics of low water flows (amplitude, duration and frequency), as well as the geographical and climatic specificities of the region (Edgar, 2008). Depending on the field of study, different indices exist to describe low water levels (Smakhtin, 2001; Hisdal \& Tallaksen, 2004; WMO, 2008; Garcia, 2016). These indices serve as thresholds for the development of different water resource management rules, leading, for example, to the limitation of withdrawals. It is therefore important to be able to know these different indices at any point in the watercourse and to be able to assess the different impacts that can influence their values (Lang, 2011). The low flow analysis provides crucial information for the planning and design water resource development, risk assessment and environmental flow management (Assefa \& Moges, 2018). Understanding the low flow regimes and evaluating the magnitudes for incorporating in water resources management are vital for countries like Cote d'Ivoire. However, studies on low water flows in Côte d'Ivoire are still limited. Some studies have focused on the evaluation of the physical, chemical and bacteriological parameters of the Aghion lagoon during the low water period (Traoré et al., 2012) and the characterization of low water flows on the N'zi-Bandama River (Kouassi et al., 2018).

The watershed of the Sassandra River, which is the subject of this study, is continually under heavy human pressure because of agricultural activities, the construction of a hydro-electric dam, and water management linked to the water supply for the population. For rational management of the surface water resources of the Sassandra River, the assessment of low flow is important. Anticipation of low water periods is therefore necessary to improve water management and take appropriate measures to mitigate the socio-economic and ecological impacts of water use restrictions. In addition, the prospect of lower water levels in a climate change context highlights the need for appropriate management tools to predict low flows.

The objective of this study is to characterize and analyze the spatial-temporal evolution of low flows in the Sassandra catchment area of Cote d'Ivoire to improving water resource management. 


\section{Site Description}

The Sassandra River watershed covers have an estimated 75,000 $\mathrm{km}^{2}$. The Sassandra watershed lies in the northwestern, western and southwestern part of Côte d'Ivoire between latitudes of $5^{\circ}$ and $10^{\circ} 25^{\prime} \mathrm{N}$ and longitudes of $6^{\circ} 25^{\prime} \mathrm{W}$ and $8^{\circ} 27^{\prime} \mathrm{W}$. It is limited to the north by the Niger River watershed, on the east of the Bandama River, on the West by the Cavally River and on the South by the Atlantic Ocean (Figure 1). The main tributaries of the Sassandra River are the Bafing and N'zo rivers on the right bank and the Lobo and Davo rivers on the left bank. Sassandra watershed spreads over four different climatic and hydrographic regions because its regime follows the rainy seasons (Kouassi et al., 2018). Its northern part is characterized by dry sub-tropical climate (between $1000 \mathrm{~mm}$ and $1700 \mathrm{~mm}$ ). This area has unimodal rainfall distribution or pattern with distinct wet (rainy) and dry seasons. The central (equatorial climate) and southern (humid equatorial climate) parts of the basin are characterized by two rainy seasons. In equatorial climate, the annual rainfall is greater than $1500 \mathrm{~mm}$. The amount of rainfall is higher in the humid equatorial climate, with a yearly mean of $1800 \mathrm{~mm}$. The western part is characterized by mountain climate (between

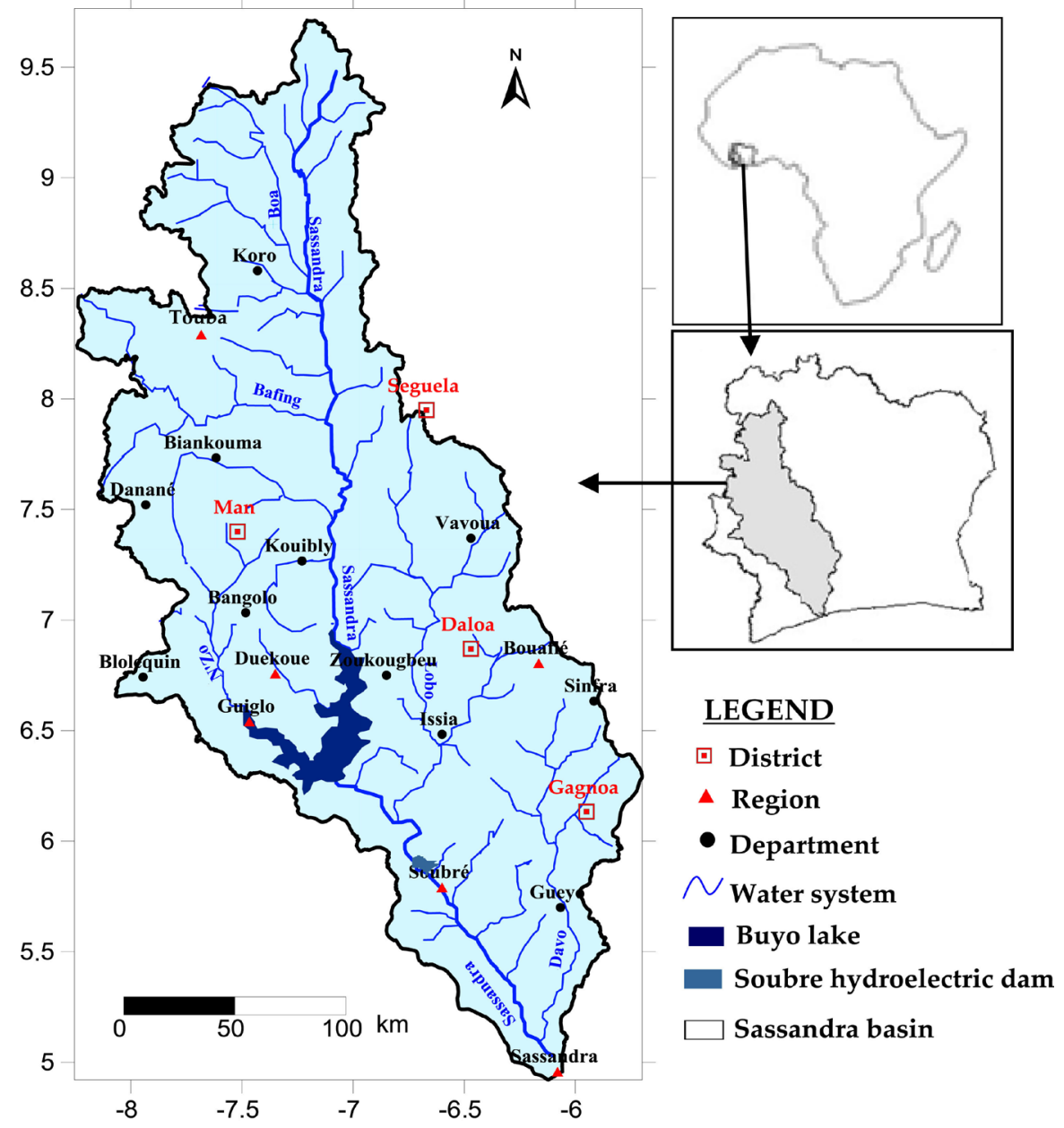

Figure 1. Geographic location of study area. 
$1000 \mathrm{~mm}$ and $1800 \mathrm{~mm})$.

As described in previous studies (Goula et al., 2010), the lithology is characterized by the birimian formation, granitoid eburnean and archeen formation. Vegetation cover in Sassandra catchment varies for northen (Savannah) to south (forest). Topography of the Sassandra catchment is gentle, with a maximum of $1180 \mathrm{~m}$ about sea level.

\section{Materials and Methods}

\subsection{Historical Time Series Data}

Historical meteorological and hydrological data were collected from the department of meteorology and hydraulic infrastructure division, Government of Cote d'Ivoire. In this study, climate data include details of rainfall. The hydrological data include meaning the daily flow of the Sassandra river and its tributaries (Bafing, Boa, Davo, Guéri, Ko, Lobo, and N'zo). Meteorological and hydrological data cover the period from 1970 to 2015 . The selection was based on the long record of data, less missing records, and functionality, the geographical position of hydroelectric dams and the consideration of the spatial climatic areas across in the Sassandra basin (Figure 2). The list of historical data as is presented in Table 1 and Table 2.

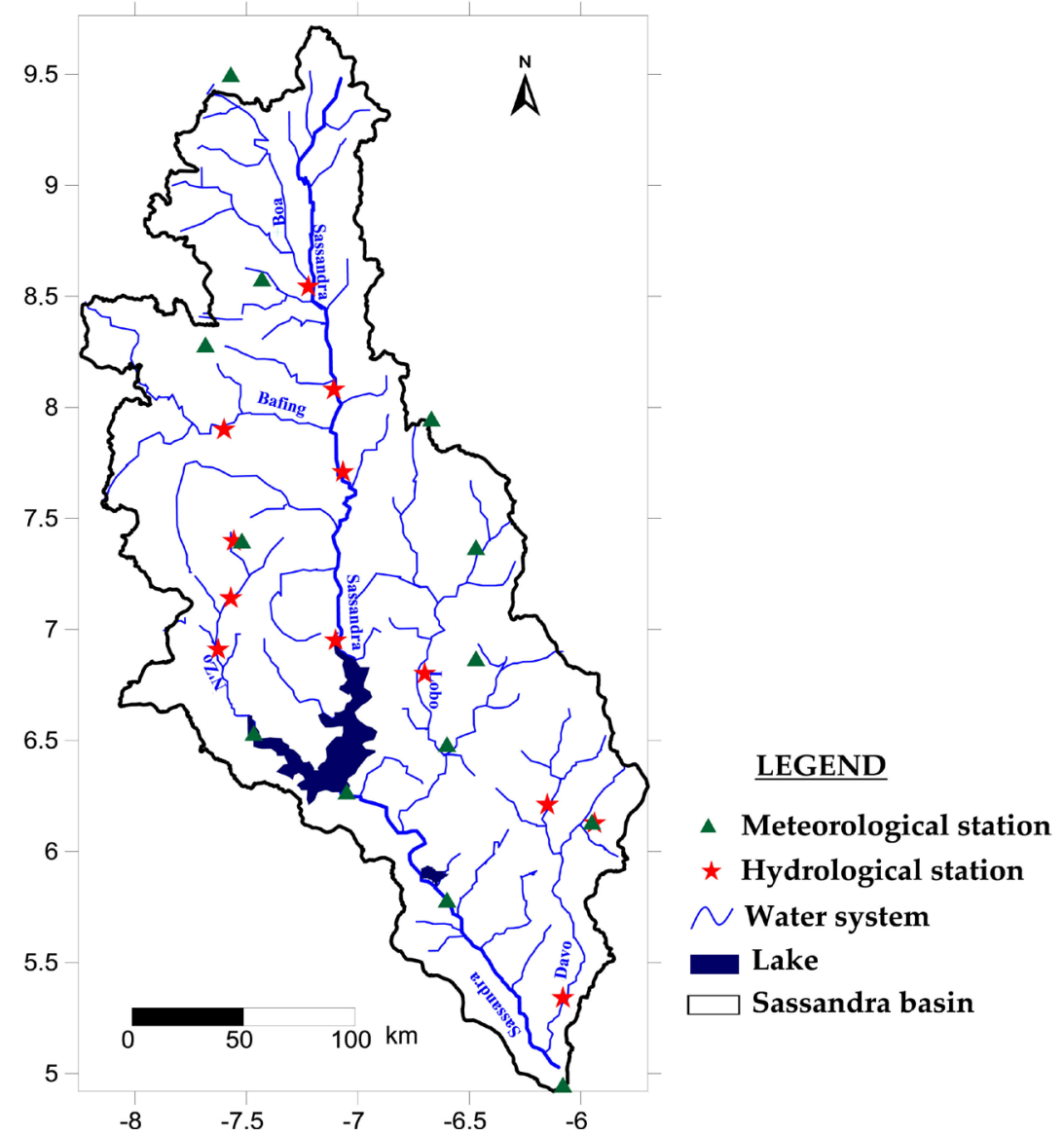

Figure 2. Network of meteorological and hydrological stations used in this study. 
Table 1. Characteristics of the hydrological stations.

\begin{tabular}{ccccc}
\hline \multirow{2}{*}{ River } & Station & \multicolumn{2}{c}{ Geographical position in decimal degree } & \multirow{2}{*}{ Area in $\mathrm{Km}^{2}$} \\
\cline { 3 - 4 } & & latitude & Longitude & \\
\cline { 3 - 4 } Bafing & Badala & 7.90 & -7.60 & 6000 \\
\multirow{2}{*}{ Boa } & Vialadougou & 8.54 & -7.22 & 5825 \\
& Dakpadou & 5.34 & -6.08 & 6818 \\
Guéri & Gagnoa-Issia & 6.17 & -6.10 & 2670 \\
& Gagnoa & 6.13 & -5.94 & 700 \\
Ko & Logoualé & 7.09 & -7.54 & 1530 \\
& Man & 7.40 & -7.56 & 210 \\
Lobo & Nibéhibé & 6.80 & -6.70 & 7280 \\
N'zo & Kahin & 6.91 & -7.63 & 4310 \\
& Guessabo & 6.95 & -7.10 & 35,000 \\
\multirow{2}{*}{ Sassandra } & Sémien & 7.71 & -7.07 & 29,300 \\
& Sorotona & 8.08 & -7.12 & 18,500 \\
\hline
\end{tabular}

Table 2. Characteristics of the hydrological stations.

\begin{tabular}{ccc}
\hline Station & \multicolumn{2}{c}{ Geographical position in decimal degree } \\
\cline { 2 - 3 } & Latitude & Longitude \\
\hline Buyo & 6.27 & -7.05 \\
Daloa & 6.87 & -6.47 \\
Gagnoa & 6.13 & -5.95 \\
Guiglo & 6.53 & -7.47 \\
Issia & 6.48 & -6.60 \\
Koro & 8.58 & -7.43 \\
Man & 7.4 & -7.52 \\
Odienne & 9.5 & -7.57 \\
Sassandra & 4.95 & -6.08 \\
Seguela & 7.95 & -6.67 \\
Soubre & 5.78 & -6.60 \\
Touba & 8.28 & -7.68 \\
Vavoua & 7.37 & -6.47 \\
\hline
\end{tabular}

\subsection{Low-Flows Indices}

Various indices have been defined to characterize low water levels and the impacts they can have on water resources (Dkengne, 2006; Lang, 2007; Benyahya et al., 2009; Pushpalatha et al., 2012; Mekhloufi, 2014; Doucet-Généreux, 2015; Nicole et al., 2015; Garcia, 2016). These low-flow indices are statistically derived from a chronic flow. In this study, we used low-flow severity indices. The fol- 
lowing indices were selected: $\mathrm{Q}_{90}, \mathrm{MAM}_{3}, \mathrm{MAM}_{7}, \mathrm{MAM}_{10}, \mathrm{QMNA}$, and ALW.

- $\mathrm{Q}_{90}$ is derived from the flow-duration curve, calculated over all the available years. $Q_{90}$ is the discharge exceeded $90 \%$ of the time.

- $\mathrm{MAM}_{3}, \mathrm{MAM}_{5}, \mathrm{MAM}_{7}$, and $\mathrm{MAM}_{10}$ are the mean annual 3-, 5-, 7- and 10-day minimum discharge, respectively. The annual minimum has derived from a daily flow series by selecting the lowest flow every year and the mean of the minima calculated. The monthly periods from January to March and February to May, according to the climatic zone. Minimum of different durations can be determined, with 3, 57 and 10 days is commonly used (Lang, 2011; Garcia, 2016; Thomas et al., 2019). The number of days is often chosen to smooth the effects of measurement errors in the flow or the effets of human activities.

- QMNA is the annual minimum monthly discharge. The low-flow indice is widely used (Catalogne, 2006; Lang, 2007; Lang, 2011; Traoré et al., 2012; Gailliez, 2013; Garcia, 2016) for low-flow management and drought management plans.

- Absolute low water: The minimum daily flow per year

\subsection{Autocorrelation Coefficient}

Before applying the statistical tests, an exploratory analysis consisting of the study of the basic statistics and the serial dependence of the low-flow index was carried out. The analysis of serial dependence is based on the calculation of the first-order autocorrelation coefficient using the Wald-Wolfowitz non-parametric test (Wald \& Wolfowitz, 1943). The significance level of this test is 5\%.

$$
r_{1}=\frac{\sum_{i=1}^{n-1}\left(x_{i}-\bar{x}\right)\left(x_{i+1}-\bar{x}\right)}{\sum_{i=1}^{n}\left(x_{i}-\bar{x}\right)^{2}}
$$

where,

$r_{1}: 1$ order autocorrelation coefficient.

$x$ : annual low-flow $i$;

$\bar{X}$ : mean low-flow over the period observation.

$$
Z=\frac{r_{1}-(-1 / n)}{\sqrt{\sigma}}
$$

where,

n: number of the value

$\sigma:$ Variance

"No autocorrelation" if $Z<1.96$; "autocorrelation" if $Z \geq 1.96$.

\subsection{Mann-Kendall Trend Test}

Evaluating the presence and absence of trends in low flow for the selected stations were carried out by using the Mann and Kendall (MK) trend test (Kendall, 1975). MK trend test (Equations (3)-(5)) evaluates and indicates the absence and 
presence of the monotonic increasing/decreasing trend. This statistical test has a variety of applications for trend analysis (Temesgen et al., 2014; Assefa \& Moges, 2018; Thomas et al., 2019). The non-parametric Mann-Kendall statistical test has been affected and the most used to assess the significance of the trend in low-flow indices. That means that we will not make any assumptions about the distribution of the random variable. Its results are relevant as long as $n(n-$ range of the file). The data must be ordered chronologically in terms of one or more criteria. This test is based on the calculation of a special statistical value $S$. Comparing each of the couples $y_{p}, y_{j}(i>j)$ of the random value $Y$, it is possible to determine if $y_{i}>y_{j}$ or $y_{i}<y_{j}$ Let's define the number of the first type as $P$ and of the second as $M$. Now $\mathrm{S}$ can be defined as:

$$
S=P-M
$$

The next Mann-Kendall statistic $Z$ has a normal distribution, where

$$
\begin{array}{ll}
Z=\frac{S-1}{\sqrt{\operatorname{var}(S)}} & \text { if } S>0 \\
Z=0 & \text { if } S=0 \\
Z=\frac{S+1}{\sqrt{\operatorname{var}(S)}} & \text { if } S<0
\end{array}
$$

The $\operatorname{var}(S)$ is defined as:

$$
\operatorname{var}(S)=n(n-1)(2 n+5)-\sum_{i=1}^{n} t_{i} i(i-1) / 18
$$

where

$n \ldots$ is the number of samples

The hypothesis H0: no trend "not reject", if $Z<Z_{\alpha / 2}$ or "reject" if $Z>Z_{\alpha / 2}$. The value $\alpha$ is called the significance level; we choose $\alpha=0.05$. The calculation of probability of normalized $Z$ test statistics is done using the application of the standard normal distribution, which is basically given by following expression:

$$
f(z)=\frac{1}{\sqrt{2 \pi}} \mathrm{e}^{\frac{z^{2}}{2}}
$$

Moreover, the value of $Z$ gives further information about any increasing of the trend, but not is magnitude exactly.

Hydrospect software 2.0 was used for trend testing.

\subsection{Cumulate Sum Test}

The parametric cumulate sum statistical test is applied to detect trends in the data series. This statistical test is based on the assumption that the number of values in the series before and after the median is the same. This method is based on a confidence interval $\left(C_{j x}\right)$.

The value is calculated for each year $X_{i}$. This value must be within the confidence interval and set at $98 \%$. If, the value $C_{j}$ comes out of this interval we consider that the mean is not stationary. 


$$
\begin{gathered}
C_{j}=\sum_{i+1}^{n}\left(x_{i}-\bar{x}\right) \\
C_{j x}= \pm S\left(\frac{u \sqrt{N}}{4}+\frac{u^{2}}{2 \sqrt{2}}+\frac{u^{3}}{8 \sqrt{N}}\right)
\end{gathered}
$$

where

$u=$ Gauss variable

$N=$ numbers of value

$S=$ standard deviation of $N$.

Hydrospect software 2.0 was used for change point testing.

\section{Resultats and Discussion}

\subsection{Low Flow Indices Analysis}

The seven low flow data extraction models $\left(\mathrm{MAM}_{3}, \mathrm{MAM}_{5}, \mathrm{MAM}_{7}, \mathrm{MAM}_{10}\right.$, QMNA, $Q_{90}$, and ALW) in the selected twelve stations have been summarized and presented in Table 3. Descriptive statistics of the low flow data were presented in Table 3. The maximum low flow indices have been observed in the Sassandra river at Guessabo station with $270.98 \mathrm{~m}^{3} / \mathrm{Sec}\left(\mathrm{MAM}_{10}\right)$. The lowest observed in the Gueri River at Gagnoa Station with $0.03 \mathrm{~m}^{3} / \mathrm{Sec}$ (ALW).

\subsection{Low-Flow Variability Analysis}

The analysis of the variability low-flow indices shows that the main river and its tributaries decrease in low-flow rates during 1970-2004 (Figure 3). These decrease inflows during low-water periods were felt on the N'zo and the main river at Semien. After 2004, there was an increase in flows during low-water periods throughout the basin.

This increase in flows from 2004 may be due to a recovery in rainfall and to the sharp deterioration of surface conditions by the intensification of agricultural activities. This increase in runoff was highlighted by N'go et al., 2013 and Yao, 2015 in the Sassandra Basin. The results of the study on the increase of flows are similar to those conducted in southern Côte d'Ivoire (Kouassi et al., 2010) and in West Africa (Amogu et al., 2010, 2015; Descroix et al., 2015). These authors have clearly shown that a reduction of the vegetal cover increases the water slides.

\subsection{Rainfall Interannual Variability Analysis}

The evolution of rainfall indices shows that two major climatic periods have marked the rainfall variability of the Sassandra basin (Figure 4). This is a period with a rainfall deficit from the 1970-2015 average. These rainfall deficits were observed in Gagnoa (1970 to 2001), Odienné (1983 to 1997) and Sassandra (1982 to 2000). This period indicates a generally dry climate. After this long dry period, there was a wet period characterized by excess rainfall indices. This wet phase covers the periods 2002 to 2015 (Gagnoa) 1970 to 1982 (Odienné and Sassandra), 2004 to 2015 (Odienné) and 1993 to 2001 (Man). 
Table 3. Statistical characteristics of the low-flow indices in the Sassandra basin.

\begin{tabular}{|c|c|c|c|c|c|c|c|c|c|}
\hline \multirow{2}{*}{ River } & \multirow{2}{*}{ Station } & \multicolumn{8}{|c|}{ Statistical characteristics of low-flow indices $\left(\mathrm{m}^{3} / \mathrm{s}\right)$} \\
\hline & & & $\mathrm{MAM}_{3}$ & $\mathrm{MAM}_{5}$ & $\mathrm{MAM}_{7}$ & $\mathrm{MAM}_{10}$ & QMNA & $\mathrm{Q}_{90}$ & ALW \\
\hline \multirow{3}{*}{ Bafing } & \multirow{3}{*}{ Badala } & $\operatorname{Max}$ & 15.27 & 15.44 & 15.67 & 16.03 & 23.22 & 16.90 & 15.00 \\
\hline & & Mean & 3.63 & 3.80 & 3.96 & 4.16 & 6.10 & 4.26 & 3.11 \\
\hline & & Min & 0.07 & 0.07 & 0.07 & 0.07 & 0.17 & 0.08 & 0.07 \\
\hline \multirow{3}{*}{ Boa } & \multirow{3}{*}{ Vialadougou } & Max & 17.78 & 19.27 & 20.42 & 22.98 & 16.60 & 7.60 & 3.07 \\
\hline & & Mean & 1.79 & 1.91 & 1.97 & 2.09 & 2.65 & 1.86 & 1.40 \\
\hline & & Min & 0.02 & 0.03 & 0.04 & 0.05 & 0.13 & 0.10 & 0.02 \\
\hline \multirow{6}{*}{ Davo } & \multirow{3}{*}{ Dakpadou } & $\operatorname{Max}$ & 7.59 & 8.11 & 8.89 & 9.59 & 12.46 & 5.37 & 2.87 \\
\hline & & Mean & 1.05 & 1.14 & 1.22 & 1.33 & 2.56 & 1.25 & 0.78 \\
\hline & & Min & 0.002 & 0.002 & 0.007 & 0.019 & 0.134 & 0.002 & 0.001 \\
\hline & \multirow{3}{*}{ Gagnoa-Issia } & $\operatorname{Max}$ & 1.37 & 1.64 & 1.81 & 2.00 & 2.65 & 1.84 & 1.37 \\
\hline & & Mean & 0.16 & 0.18 & 0.20 & 0.23 & 0.43 & 0.21 & 0.13 \\
\hline & & Min & 0.001 & 0.003 & 0.004 & 0.006 & 0.026 & 0.007 & 0.001 \\
\hline \multirow{4}{*}{ Guéri } & \multirow{4}{*}{ Gagnoa } & Max & 0.37 & 0.39 & 0.43 & 0.46 & 0.49 & 0.23 & 0.14 \\
\hline & & Mean & 0.05 & 0.05 & 0.06 & 0.06 & 0.12 & 0.05 & 0.03 \\
\hline & & Min & 0.0002 & 0.001 & 0.002 & 0.002 & 0.006 & 0.002 & 0.0002 \\
\hline & & Max & 10.07 & 10.45 & 11.01 & 15.22 & 26.81 & 6.72 & 2.75 \\
\hline \multirow{5}{*}{ Ko } & \multirow[t]{2}{*}{ Logouale } & Mean & 0.71 & 0.91 & 0.98 & 1.23 & 1.82 & 0.76 & 0.37 \\
\hline & & Min & 0.002 & 0.005 & 0.011 & 0.016 & 0.096 & 0.014 & 0.001 \\
\hline & \multirow{3}{*}{ Man } & Max & 1.76 & 1.83 & 1.93 & 2.45 & 2.35 & 0.69 & 0.52 \\
\hline & & Mean & 0.18 & 0.21 & 0.22 & 0.26 & 0.38 & 0.19 & 0.12 \\
\hline & & Min & 0.004 & 0.006 & 0.009 & 0.009 & 0.043 & 0.01 & 0.001 \\
\hline \multirow{3}{*}{ Lobo } & \multirow{3}{*}{ Nibéhibé } & Max & 1.32 & 1.36 & 1.41 & 1.68 & 26.81 & 1.59 & 1.21 \\
\hline & & Mean & 0.25 & 0.27 & 0.28 & 0.31 & 1.82 & 0.29 & 0.20 \\
\hline & & Min & 0.001 & 0.002 & 0.003 & 0.004 & 0.096 & 0.01 & 0.001 \\
\hline \multirow{3}{*}{ N’zo } & \multirow{3}{*}{ Kahin } & Max & 69.51 & 72.12 & 75.96 & 96.60 & 36.16 & 26.53 & 9.49 \\
\hline & & Mean & 3.51 & 3.81 & 4.02 & 4.67 & 5.11 & 2.94 & 1.54 \\
\hline & & Min & 0.014 & 0.02 & 0.029 & 0.033 & 0.117 & 0.040 & 0.006 \\
\hline \multirow{9}{*}{ Sassandra } & \multirow{3}{*}{ Guéssabo } & Max & 194.98 & 202.30 & 213.06 & 270.98 & 101.42 & 74.43 & 53.24 \\
\hline & & Mean & 13.59 & 14.21 & 14.79 & 16.61 & 16.50 & 11.76 & 8.90 \\
\hline & & Min & 0.02 & 0.02 & 0.02 & 0.02 & 0.10 & 0.03 & 0.02 \\
\hline & \multirow{3}{*}{ Sémien } & Max & 121.18 & 131.36 & 139.14 & 156.59 & 113.16 & 51.78 & 32.20 \\
\hline & & Mean & 11.38 & 11.91 & 12.39 & 13.30 & 16.88 & 11.90 & 8.89 \\
\hline & & Min & 0.35 & 0.35 & 0.35 & 0.35 & 0.80 & 0.41 & 0.31 \\
\hline & \multirow{3}{*}{ Sorotona } & Max & 67.88 & 73.58 & 77.94 & 87.71 & 63.38 & 29.00 & 11.70 \\
\hline & & Mean & 6.65 & 6.97 & 7.22 & 7.70 & 9.58 & 6.81 & 5.18 \\
\hline & & Min & 0.20 & 0.20 & 0.20 & 0.20 & 0.45 & 0.23 & 0.20 \\
\hline
\end{tabular}




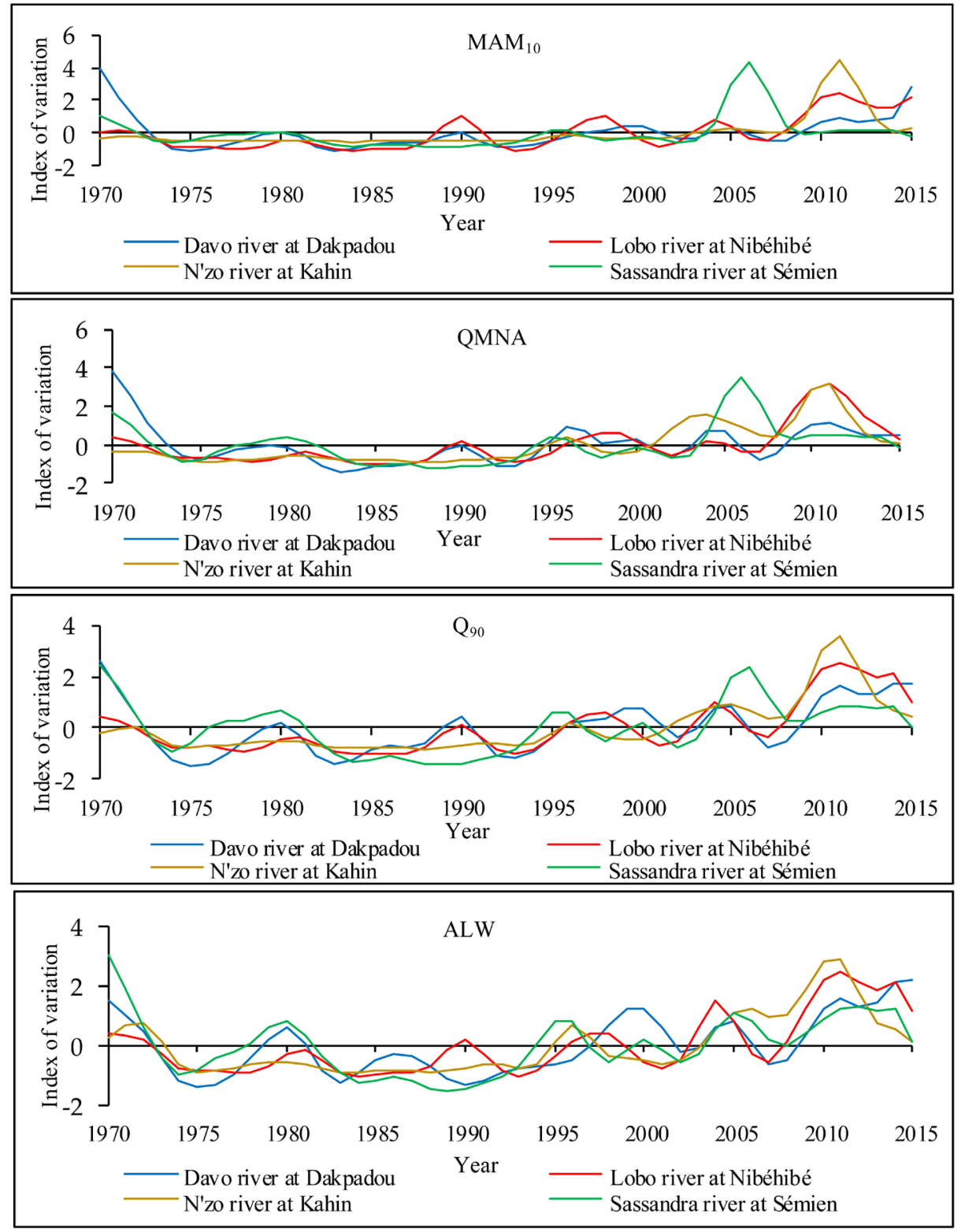

Figure 3. Representation of the interannual $\mathrm{MAM}_{10}, \mathrm{QMNA}, \mathrm{Q}_{90}$ and ALW observed in the period 1970-2015 for the Sassandra watershed.

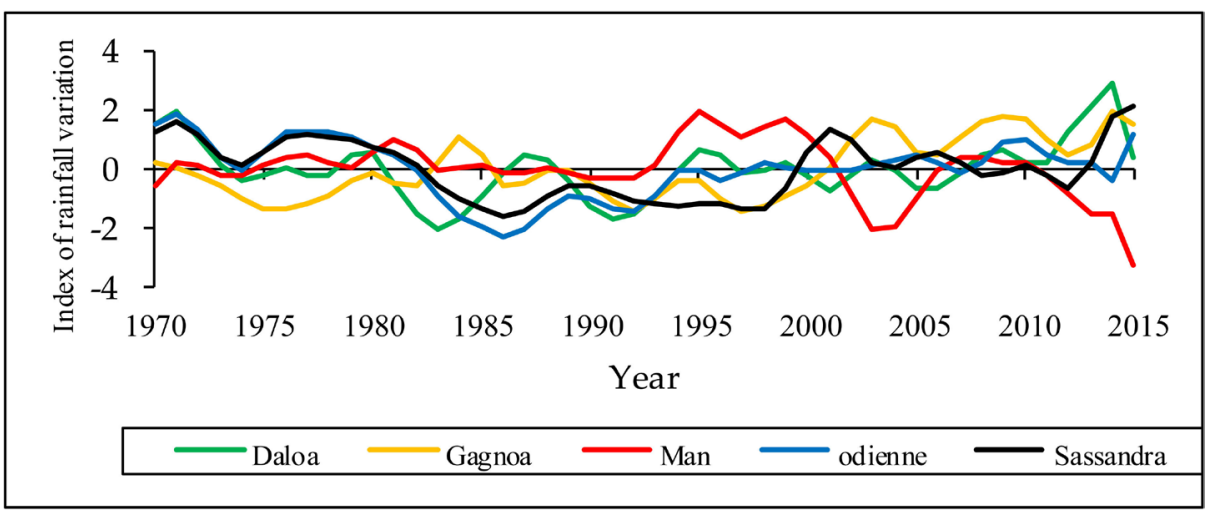

Figure 4. Representation of the interannual rainfall for the Sassandra watershed. 


\subsection{Low-Flow Serial Dependence Analysis}

The Analyses show that the majority of low-flow index series do not have an autocorrelation structure (Table 4). Table 4 indicates a significant autocorrelation at a risk of 5\%. Boa River at Vialadougou, Ko River at Man, and Sassandra River at Guessabo stations most affected by this positive autocorrelation.

Analysis of low-flow indices in the Sassandra catchment indicates that very few series are affected by significant serial dependence. This indicates that any observed gradual changes are not related to significant serial dependence. Indeed, the existence of dependencies can affect the results of the trend analysis. According to (Hamed, 2009), the presence of significant autocorrelation or serial dependence causes a high rate of rejection of the stationarity hypothesis (no trend).

\subsection{Low Flow Trend Analysis Resultat}

The trend test for low flow average and variance for the selected stations were carried out by using the Mann-Kendall (MK) test as discussed in the methodology section. The majority of the trends detected on the low-flow are high amplitude (significance level $95 \%$ to $99 \%$ ). As presented in Figure 5 nearly 7 of the selected station have indicated an increasing trend with the positive change of low flow values of $67 \%\left(\mathrm{Q}_{90}\right)$ and $42 \%$ (QMNA). The Ko, N'zo, and Gueri rivers are more affected by this change. The Bafing River at Badala, Sassandra River at Sorotona, Sassandra River at Semien and Ko River at Man stations have indicated no significant trend. It is very difficult to identify a real spatial consistency in the trends observed, even if some trends observed in the average seem to be clustered in the West, Center, and East of the watershed. Figure 6 presents trends

Table 4. First-order autocorrelation coefficient of the low-flow indices.

\begin{tabular}{|c|c|c|c|c|c|c|c|c|}
\hline \multirow{2}{*}{ Stream } & \multirow{2}{*}{ Station } & \multicolumn{7}{|c|}{ First-order autocorrelation coefficient } \\
\hline & & $\mathrm{MAM}_{3}$ & $\mathrm{MAM}_{5}$ & $\mathrm{MAM}_{7}$ & $\mathrm{MAM}_{10}$ & QMNA & $\mathrm{Q}_{90}$ & ALW \\
\hline Bafing & Badala & 1.80 & 1.70 & 1.56 & 1.43 & 2.23 & 1.78 & 1.45 \\
\hline Boa & Vialadougou & 2.40 & 2.73 & 2.75 & 2.78 & 1.88 & 2.88 & 2.41 \\
\hline \multirow{2}{*}{ Davo } & Dakpadou & -0.06 & -0.02 & -0.04 & -0.13 & 0.92 & -0.02 & 1.02 \\
\hline & Gagnoa-Issia & 0.55 & 0.40 & 0.40 & 0.35 & 2.03 & 0.80 & 0.66 \\
\hline Guéri & Gagnoa & -0.14 & -0.26 & -0.32 & -0.49 & 1.98 & -0.36 & 1.90 \\
\hline \multirow{2}{*}{ Ko } & Logoualé & -0.18 & -0.23 & -0.15 & 0.001 & 0.73 & 0.55 & 0.43 \\
\hline & Man & 2.74 & 2.53 & 2.38 & 2.07 & 4.12 & 3.95 & 3.33 \\
\hline Lobo & Nibéhibé & -0.67 & -0.68 & -0.69 & -0.73 & 0.002 & -0.89 & -0.68 \\
\hline \multirow[t]{2}{*}{ N’zo } & Kahin & -0.53 & -0.56 & -0.58 & -0.55 & 0.22 & -0.28 & -0.43 \\
\hline & Guéssabo & 2.58 & 2.52 & 2.46 & 2.50 & 2.64 & 2.64 & 2.68 \\
\hline \multirow[t]{2}{*}{ Sassandra } & Sémien & 1.70 & 1.67 & 1.62 & 1.65 & 2.21 & 2.15 & 1.73 \\
\hline & Sorotona & 1.60 & 1.56 & 1.53 & 1.33 & 1.14 & 1.26 & 1.37 \\
\hline
\end{tabular}

Bold number indicates a significant autocorrelation at risk of $5 \%$. 

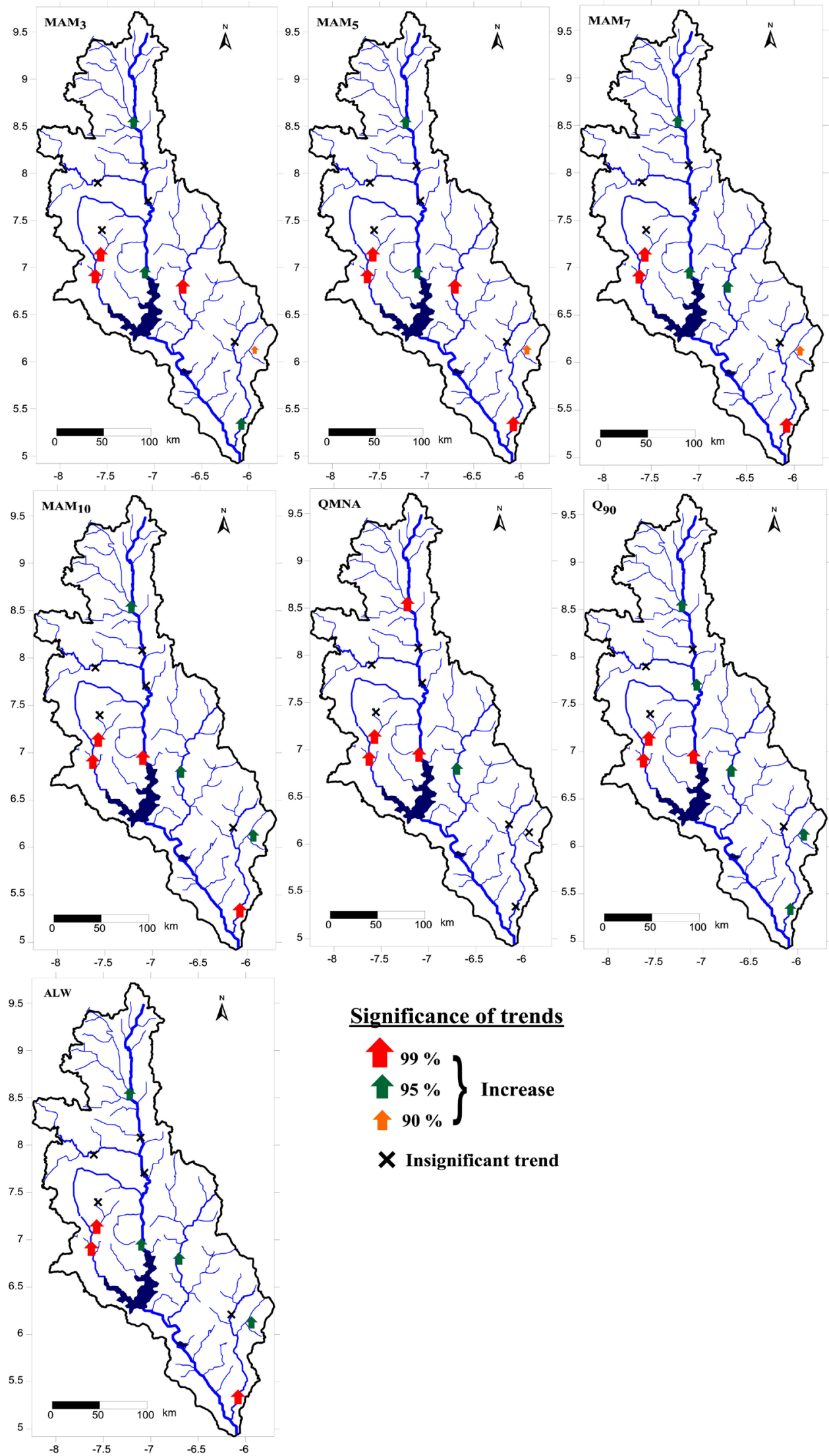

Significance of trends

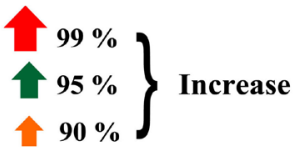

$X$ Insignificant trend

Figure 5. Trends observed on the mean low-flow index. 

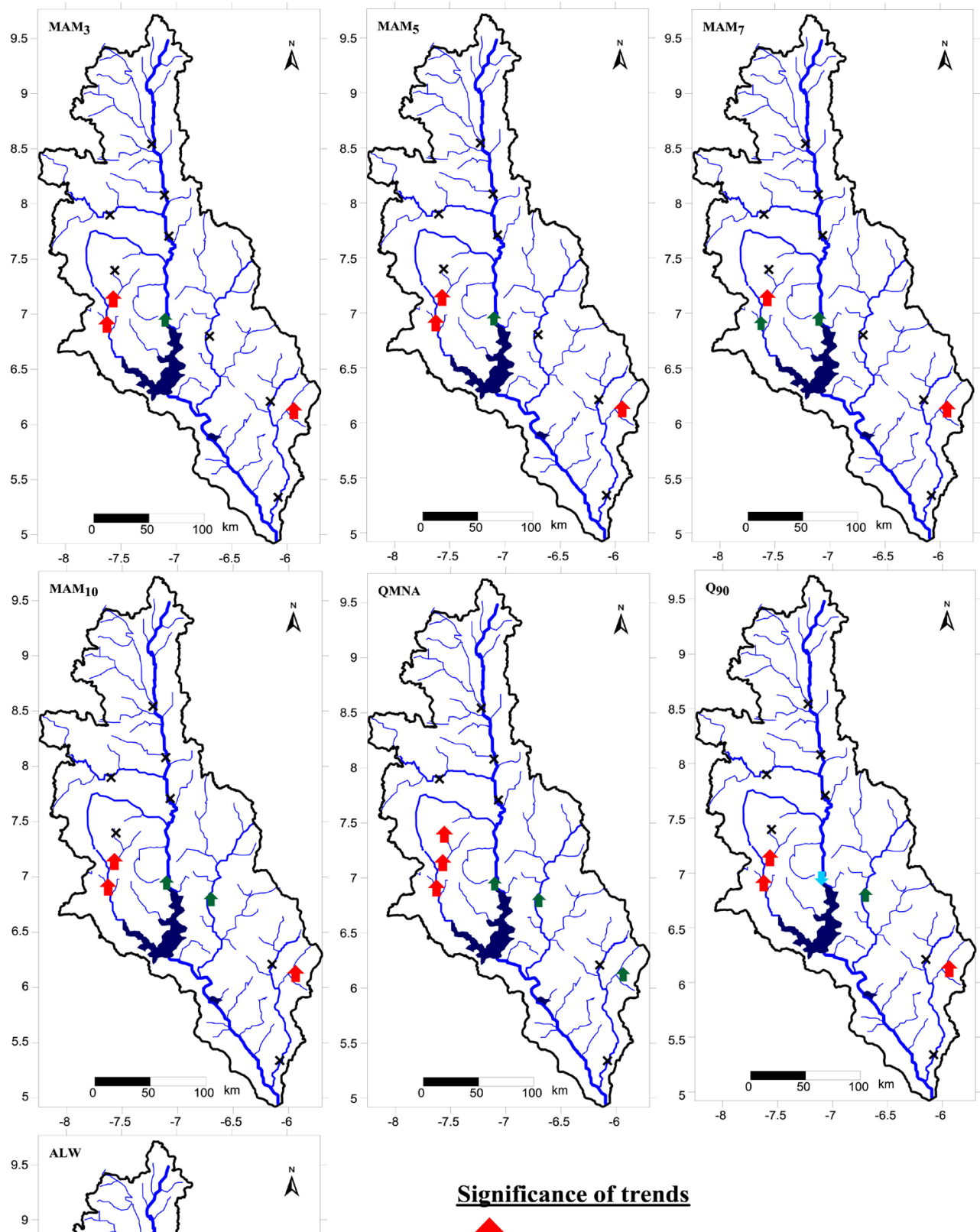

Significance of trends
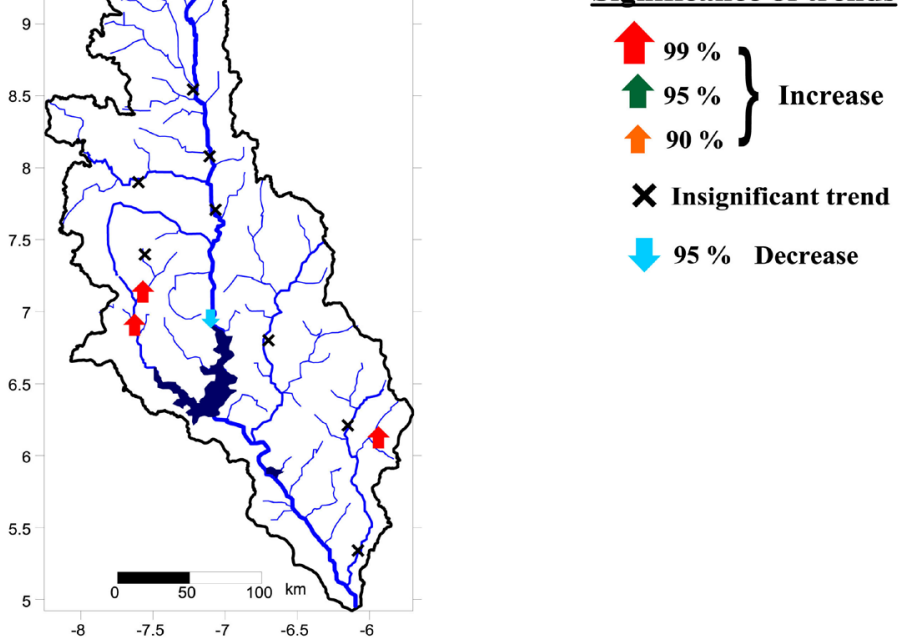

$X$ Insignificant trend

$95 \%$ Decrease

Figure 6. Trends observed on the variance low-flow index. 
in the variance of low flow. The results indicate that 25\% (ALW) to 50\% (QMNA) of the stations presents an increasing trend. $\mathrm{Q}_{90}$ and ALW low flows at the Guessabo station show a decreasing trend. Increasing trends in low flow variance are observed in the west and southeast of the Sassandra basin.

There could be several reasons for the increase in low flows in the Sassandra Basin. Some of this includes changes in physical characteristics of catchment such as the land cover change in the river basin. For instance, the change of the forest to agricultural land could largely increase runoff in the rainy season and recovery of heavy rainfall after the year 1990 in West Africa. This has been indicated in different studies such as (Descroix et al., 2013; Sighomnou et al., 2013; Cissé et al., 2014; Panthou et al., 2014; Yao, 2015; Kouamé, 2017; Assefa \& Moges, 2018). In addition, analyses using the Mann-Kendall statistical test showed that 50 to $67 \%$ of low-flow series do not show significant trends in variance. These insignificant trends are particularly observed in the main river and some of its tributaries. The absence of generalized trends in low-flow series has also been observed in Canada by Ehsanzadeh \& Adamowski, 2007. The general lack of consistency in low water levels can be explained by the existence of undeclared hydraulic installations on rivers. These hydraulic installations really disturb the regimes by subjecting them to anthropogenic fluctuations. There are other factors that influence minimum flows and often make it difficult to detect trends: geological, hydrogeological and soil conditions, climate, basin size, and vegetative conditions. These factors have the potential to influence low water flows in the dry period.

\subsection{Low Flow Change-Point Analysis Resultat}

The change point of low flow average and variance for the selected stations were carried out by using cumulate sum test as discussed in the methodology section. Figure 7 and Figure 8 shows a change point in the low flow. All $M_{4}$ and $\mathrm{MAM}_{10}$ low flow stations detected significant a change point. The change point detection was between 1988 and 2007. Vialadougou, semien and sorotona stations have no break in the variance low flow.

[29] indicates that the change point generally observed around 1990 and 2000 in average annual flows in West Africa result from a rainfall recovery. Indeed, the sudden changes observed in the low-water level series of the Sassandra River are part of the 1990-2007 break in the rainfall and hydrological regimes of West Africa.

\section{Conclusion}

In this paper, we discussed the spatial and temporal evolution of low water flows in the Sassandra river catchment area in Cote d'Ivoire. This study focused on the daily low water $\left(\mathrm{MAM}_{3}, \mathrm{MAM}_{5}, \mathrm{MAM}_{7}\right.$, and $\left.\mathrm{MAM}_{10}\right)$, monthly (QMNA) and annual $\left(Q_{90}\right.$ and $\left.A L W\right)$ water levels. The analysis of the low-water flow shows that the station of Sassandra in Guessabo has great values while that of Gueri in 

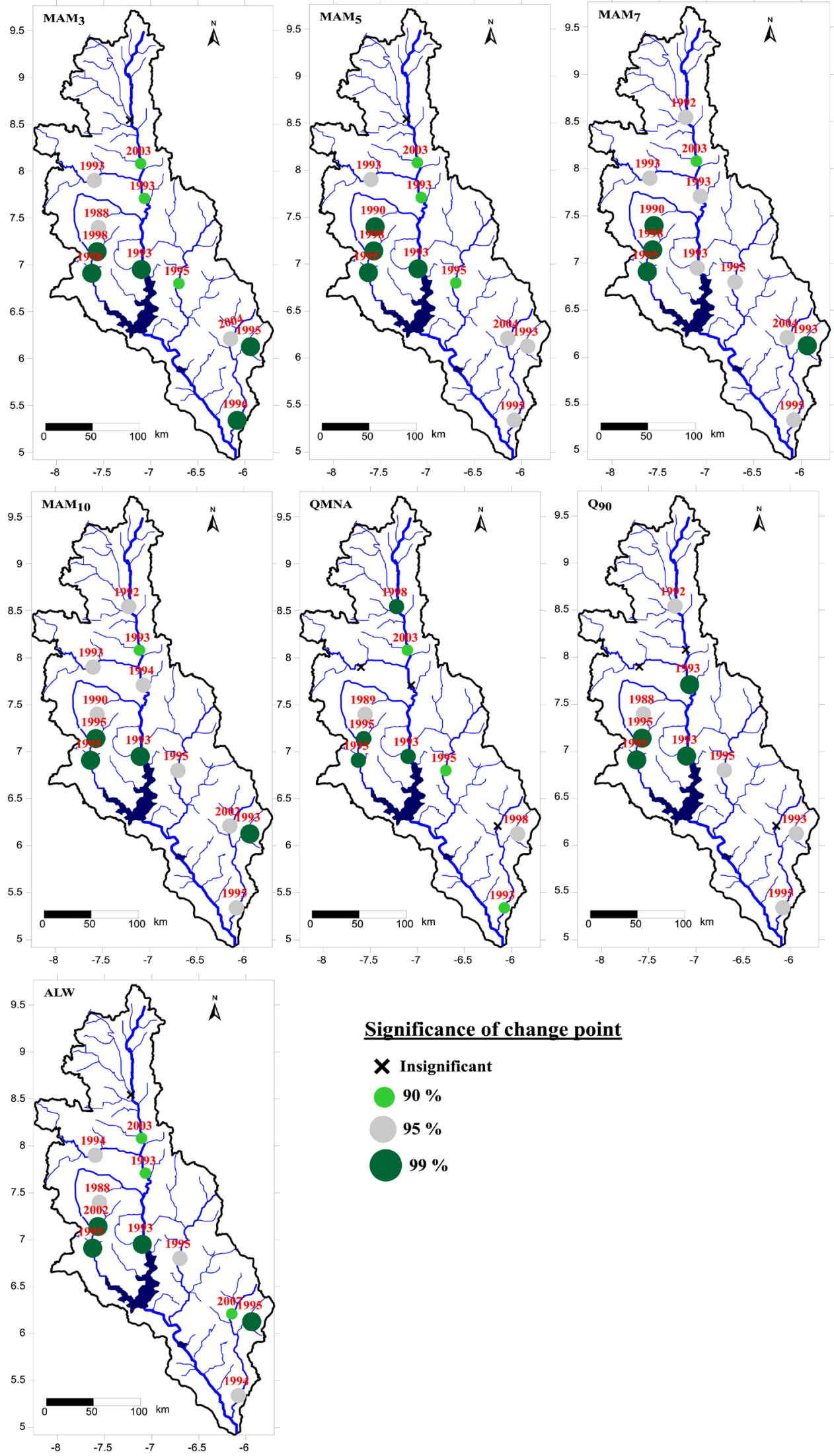

\section{Significance of change point}

$X$ Insignificant

$90 \%$

$95 \%$

$99 \%$

Figure 7. Change point on the mean of the low-flow index. 

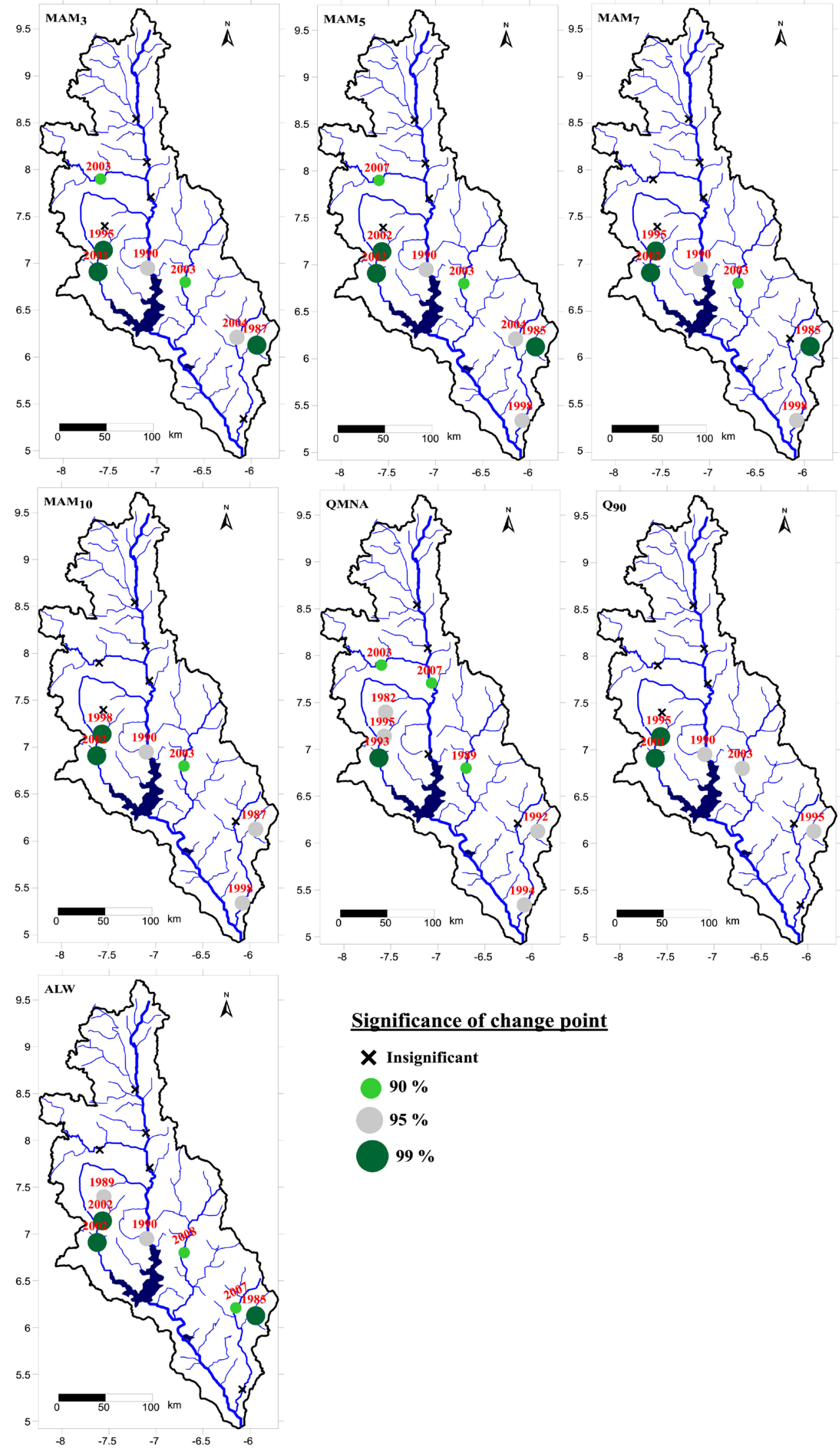

\section{Significance of change point}

$X$ Insignifican

$90 \%$

$95 \%$

$99 \%$

Figure 8. Change point on the variance of the low-flow index. 
Gagnoa has smaller values. The index of variation shows a succession of years of low water flows from 1970 to 2004 and year of strong flow from 2004 to 2015.

Statistics of the Mann-Kendall trend test showed that $67 \%$ of the hydrological stations (8 stations over a total of 12) presented an increased low flow trend whereas the rest of the stations showed an Insignificant trend. Bafing River at Badala, Sassandra River at Sorotona and Ko River at Man stations have insignificant trends on average as well as the variance in the low flow index. Results of the low flow variability showed that the low flow is high across the basin. $\mathrm{Cu}$ mulate sum was adopted to analyze the change-point of the mean and variance in the low-flow series Sudden changes is also observed in low flows, particularly between 1988-2004 (mean) and 1985-2008 (variance). However, the only results of an analysis of statistical tests are not sufficient to determine the spatiotemporal evolution of low water levels. The variation of low flows depends on human needs and rainfall. It is therefore important to combine rainfall and provide consumption flows to better adapt the hydraulic structures and prevent the risk of water shortage.

\section{Acknowledgements}

The authors thank the Department of Hydraulic Infrastructure division, Government of Côte d'Ivoire for data acquisition.

\section{Conflicts of Interest}

The authors declare no conflicts of interest regarding the publication of this paper.

\section{References}

Amogu, O., Descroix, L., Yéro, K. S., Le Breton, E., Mamadou, I., Ali, A., Vischel, T. et al. (2010). Increasing River Flows in the Sahel? Water, 2, 170-199. https://doi.org/10.3390/w2020170

Amogu, O., Esteves, M., Vandervaere, J.-P., Malam Abdou, M., Panthou, G., Rajot, J.-L., Souley Yéro, K. et al. (2015). Runoff Evolution Due to Land-Use Change in a Small Sahelian Catchment. Hydrology Sciences Journal, 60, 78-95. https://doi.org/10.1080/02626667.2014.885654

Assefa, K. \& Moges, M. A. (2018). Low Flow Trends and Frequency Analysis in the Blue Nile Basin, Ethiopia. Journal of Water Resource and Protection, 10, 182-203. https://doi.org/10.4236/jwarp.2018.102011

Benyahya, L., Daigle, A., Caissie, D., Beveridge, D., \& St-Hilaire, A. (2009). Characterization of the Natural Flow Regime of Watersheds in Eastern Canada. Master, R1057.

Catalogne, C. (2006). Improvement of Predetermination Methods for Low Flow Reference Flows in Low or Ungauged Sites. Ph.D. Thesis, Grenoble: Grénoble University.

Cissé, M., Sambou, S., Dierne, Y., Diatta, C., \& Bop, M. (2014). Analysis of Flow in the Senegal River Basin from 1960 to 2008. Journal of Water Science, 27, 167-187. https://doi.org/10.7202/1025566ar

Descroix, L., Genthon, P., Peugeot, C., Mahé, G., Abdou, M. M., Vandervaere, J.-P., Mamadou, I. et al. (2015). Paradoxes et contrastes en Afrique de l'Ouest: Impacts climati- 
ques et anthropiques sur les écoulements. Géologues, 187, 47-52.

Descroix, L., Niang, A. D., Dacosta, H., Panthou, G., \& Quantin, G. (2013). Evolution of Rainy Extreme Events and Rise in Flooding in the Sahel. Climatologie, 10, 37-49. https://doi.org/10.4267/climatologie.78

Dkengne, S. P. (2006). Modélisation et prévision des débits naturels journaliers du basin versant de la Sanaga à la station de contrôle de Songmbengue. Master, Yaoundé: Ecole Nationale Supérieure Polytechnique de Yaoundé.

Doucet-Généreux, P. L. (2015). Simulation des debits d'étiages dans un concept de changement climatique: Incertitudes lièes au choix du modèle et au critère de calage. Maitrise, Sherbrooke: Université de Sherbrooke.

Edgar, H. G. (2008). Développement d'une méthodologie hydrologique/statistique pour estimer les debits d'étiages au Québec habité. Ph.D., Quebec: Université du Quebec INRS-ETE.

Ehsanzadeh, E., \& Adamowski, K. (2007). Detection of Trends in Low Flows across Canada. Canadian Water Resources Journal, 32, 251-264. https://doi.org/10.4296/cwrj3204251

Gailliez, S. (2013). Low Flow Discharge Estimation at Ungauged Sites. Application in Walloon Region. Ph.D. Thesis, Liège: Université of Liège.

Garcia, F. (2016). Amélioration d'une modélisation hydrologique régionalisée pour estimer les statistiques d'étiage. Ph.D. Thesis, Paris: Université Pierre et Marie Curie.

Goula, B. T. A., Soro, G. E., Dao, A., Kouassi, F. W., \& Srohourou, B. (2010). Frequency Analysis and New Cartography of Extremes Daily Rainfall Events in Côte d'Ivoire. Journal of Applied Sciences, 10, 1684-1694. https://doi.org/10.3923/jas.2010.1684.1694

Hamed, K. H. (2009). Effect of Persistence on the Significance of Kendall's Tau as a Measure of Correlation between Natural Time Series. European Physical Journal Special Topics, 174, 65-79. https://doi.org/10.1140/epjst/e2009-01090-x

Hisdal, H., \& Tallaksen, L. M. (2004). Hydrological Drought Characteristics. In L. Tallaksen, \& H. A. J. Lanen (Eds.), Hydrological Drought: Processes and Estimation: Methods for Streamflow and Groundwater (pp. 139-198). Amsterdam: Elsevier.

Kendall, M. G. (1975). Rank Correlation Methods. London: Griffin.

Kouamé, Y. M. (2017). Impacts des changements climatiques et de la dynamique d'occupation du sol sur les eaux de surface dans le bassin versant de la Davo, Côte d'Ivoire. PhD Thèse, Abidjan: Université Nangui Abrogoua.

Kouassi, A. M., Karim Nassa, R. A., N’Guessan Bi, T. M., Kouamé, K. F., \& Biemi, J. (2018). Caracterisation des debits d'étiage dans un context de changements climatiques: Cas du basin versant du N'zi (Côte d'Ivoire). Agronomie Africaine, 3, 215-223.

Kouassi, A. M., Kouamé, K. F., Koffi, Y. B., Djê, K. B., Paturel, J. E., \& Oulare, S. (2010). Analysis of Climate Variability and of Its Influences on Seasonal Rainfall Regimes in West Africa: Case of the N'zi (Bandama) Watershed in Ivory Coast. European Journal of Geography, 513.

Lang, C. (2007). Etiages et tarissements: Vers quelles modélisations? L'approche conceptuelle et l'analyse statistique en réponse à la diversité spatiale des écoulements en étiage des cours d'eau de l'Est français. Ph.D. Thesis, Metz: Université de Metz.

Lang, C. (2011). Low Flows: Hydrological Aspects, Statistical Definition and Regulatory Framework. Cybergeo: European Journal of Geography, Environment, Nature, Paysage, 571 .

Mekhloufi, N. (2014). Prédetermination et prévision des étiages des oueds de l'Algérie septentrionale. Master, Algerie. 
N'go, Y. A., Ama-Abina, J. T., Kouadio, A. Z., Kouassi, H. Z., \& Kouassi, K. H. (2013). Environ-Mental Change in Agricultural Land in Southwest Côte d'Ivoire: Driving Forces and Impacts. Journal of Environmental Protection, 4, 1373-1382. https://doi.org/10.4236/jep.2013.412158

Nicole, P., Perrin, C., Andreassian, V., Augeard, D., Besson, F., Carroget, A., Francois, D., LE Lay, M., Regimbeau, F., \& Thiery, D. (2015). Prévoir les étiages: Que peut-on attendre des modèles hydrologiques. Rapport de l'office Nationale de l'Eau et des Milieux Aquatiques.

Panthou, G., Vischel, T., \& Lebel, T. (2014). Recent Trends in the Regime of Extreme Rainfall in the Central Sahel. International Journal Climatology, 34, 3998-4006. https://doi.org/10.1002/joc.3984

Pushpalatha, R., Perrin, C., Moine, N. L., \& Andreassian, V. (2012). A Review of Efficiency Criteria Suitable for Evaluating Low-Flow Simulations. Journal of Hydrology, 420, 171-182. https://doi.org/10.1016/j.jhydrol.2011.11.055

Sighomnou, D., Descroix, L., Genthon, P., Mahé, G., Moussa, I. B., Gautier, E., Mamadou, I. et al. (2013). The Niger River Niamey Flood of 2012: The Paroxysm of the Sahelian Paradox? Sécheresse.

Smakhtin, V. U. (2001). Low Flow Hydrology: A Review. Journal of hydrology, 240, 147-186. https://doi.org/10.1016/S0022-1694(00)00340-1

Temesgen, E., Meseret, B. A., Adugnaw, T., Debebe, L. Y., Azalu, A. G., Seifu, A. T., Mengiste, A. M., Fasikaw, A. Z., Mamaru, A. M., \& Tammo, S. (2014). Biohydrology of Low Flows in the Humid Ethiopian Highlands: The Gilgel Abay Catchment. Biologia, 69, 1502-1509. https://doi.org/10.2478/s11756-014-0462-9

Thomas, D. E., Venkataraman, K., Chraibi, V., \& Kannan, N. (2019). Hydrologic Trends in the Upper Nueces River Basin of Texas-Implications for Water Resource Management and Ecological Heath. Hydrology, 6, 20.

https://doi.org/10.3390/hydrology6010020

Traoré, A., Soro, G., Kouadio, K. E., Bamba, S. B., Oga, M. S., Soro, N., \& Biemi, J. (2012). Evaluation des paramètres physiques, chimiques et bactériologiques des eaux d'une lagune tropicale en période d'étiage: La lagune Aghien (Cote d'Ivoire). International Journal of Biological and Chemical Sciences, 6, 7048-7058.

https://doi.org/10.4314/ijbcs.v6i6.40

Wald, A., \& Wolfowitz, J. (1943). An Exact Test for Randomness in the Non-Parametric Case Based on Serial Correlation. Annals of Mathematical Statistics, 14, 378-388. https://doi.org/10.1214/aoms/1177731358

WMO World Meteorological Organization (2008). Manual on Low-Flow Estimation and Prediction. 1339 Operational Hydrology.

Yao, A. B. (2015). Evaluation des potentialités en eau du Bassin versant de la Lobo en vue d'une gestion rationnelle (Centre-Ouest de la Côte d'Ivoire). Ph.D. Thesis, Abidjan: Université Nangui Abrogoua. 